\author{
AMERICAN JOURNAL OF FOOD AND NUTRITION \\ Print: ISSN 2157-0167, Online: ISSN 2157-1317, doi:10.5251/ajfn.2011.1.4.193.200 \\ C 2011, ScienceHuß, http://www.scihub.org/AJFN
}

\title{
A pilot study on the aetiology of goiter in Bayelsa state, Nigeria
}

\author{
Madukosiri C.H. \\ Department of Biochemistry, Niger Delter University, Wilberforce Island, Bayelsa state, \\ Nigeria
}

\begin{abstract}
Some biochemical parameters- thiocyanate, triiodothyronine $\left(T_{3}\right)$, thyroxine $\left(T_{4}\right)$, thyroid stimulating hormone (TSH), aspartate aminotranferase (AST), alanine aminotransferase (ALT), iodine, sodium and potassium were determined from subjects (both sexes), in order to trace the aetiology of goiter observed among some persons living in Bayelsa state. Subjects were admitted into the study in accordance with the operating ethical consideration at the local medical centre. The control group constitutes those certified apparently healthy by the medical practitioner. Thiocyanate determination was done according to the modified method of Haque and Bradbury; whereas the hormonal and the enzymic studies were carried out using ELISA method. Sodium and potassium were determined by flame photometric method. The levels of the analytes determined in the test group (those with endemic goiter) were compared to their control counterparts. The mean $( \pm S D)$ thiocyanate level $(\mu \mathrm{g} / \mathrm{L})$ determined from the test group (females) was 150.5 \pm 15.78 ; whereas those from the controls were $104.7 \pm 1.93$ (Males) and $84.67 \pm 30.80$ (females); and were all higher than the literature critical range. Significant differences $(p<0.05)$ were determined between the mean serum levels of $\mathrm{T}_{3}, \mathrm{~T}_{4}, \mathrm{AST}$, and ALT, in test group and their controls. Interestingly, even the thyroid hormone levels in the control group were at the lower boarder of the reference ranges. These results suggest that the larger population out there could be at risk of developing goiter, if proper intervention measures are not instituted. The high thiocyanate levels determined could be an outcome of chronic accumulation of hydrocyanide arising from high intake of improperly processed cassava (Manihot esculenta cruntz) food products. Cassava is a major staple food in Bayelsa State and known to contain substantive level of the toxicant hydrocyanide which had been implicated in goiter development. Finally the ongoing salt iodination programme in the country, and in some other regions where it is practiced, should be done with caution. It would be worthwhile to first carry out a base-line study to determine the level of deficiency, if any, before embarking on salt fortification with iodine. This is necessary so as to avoid an over-load with the element and its attendant consequences.
\end{abstract}

Key word: Goiter, thyroid hormones, thiocyanate, iodine.

\section{INTRODUCTION}

The term goiter refers to the abnormal enlargement of the thyroid gland (Felig et al., 2001). However the presence of goiter does not necessarily mean that the thyroid gland is malfunctioning. A goiter can occur in hyperthyroidic, hypothyroidic and euthyroidic individuals. Other forms of goiter are simple goiter (enlarged thyroid gland with low hormone secretion), endemic goiter (when more than $10 \%$ of a population is affected) and sporadic goiter (occurring as a result of environmental or genetic factors that do not affect the general population), (Felig et al., 2001). Hyperthyroidism affects the number and activities of mitochondria, transport of ions (particularly those of
$\mathrm{Na}+$ and $\mathrm{K}+$ ) through cell membrane, growth functions, respiration, gastrointestinal motility, and excitatory mechanism of the central nervous system, among others, (Felig et al., 2001). On the other hand effects of hypothyroidism range from cretinism, mental abnormalities to growth retardation, (Hetzel, 1983).

One common cause of endemic goiter is iodine deficiency diseases (IDDs). lodine deficient goiter emerges as an outcome of continued stimulation (by thyroid stimulating hormone - TSH from the anterior pituitary) of the thyroid cells to secrete thyroglobulin colloid into the follicles in the absence of iodine. The result is failure of thyroid hormone production and 
Am. J. Food. Nutr, 2011, 1(4): 193-200

suppression of feedback inhibition of TSH. Continued stimulation causes the follicles to enlarge in size sometimes up to 10 to 20 times its normal size (Felig et al., 2001).

lodine deficient goiter can arise when, either the people are not getting enough of the dietary iodine, or some other endogenous factors (such as enzymic or toxicity problems) are antagonizing the uptake and utilization of absorbed iodine for onward synthesis of triiodothyronine $\left(T_{3}\right)$ and tetraiodothyronine $\left(T_{4}\right)$. Factors relating to transport mechanism of the element, metabolism and synthesis in thyroid gland, can render the absorbed iodine unavailable for those processes.

lodine deficiency is a public health problem affecting many regions of the world where soil iodine content is poor. According to World Health Organization statistics (WHO, 2001), iodine deficiency occurs in about 130 countries of the world affecting about 2.2 billion (or $38 \%$ ) of world's population. This reference estimates that about $500-850$ million people have goiter caused by iodine deficiency.

The present study was conducted in some of the local Government areas in the coastal regions of Bayelsa state, Nigeria - namely Nembe, Ogbia, and Southern ljaw. This decision was taken against the backdrop of an earlier observation that some residents in those areas showed visible evidence of goiter despite large consumption of iodine- rich foods such as periwinkle, oysters and fishes, (Madukosiri, 2011). According to this reference high levels of iodine were determined from both foods (raw and processed foods) and water. Besides, government legislature was in place enforcing the sale and use of iodized salt throughout the regions. The adequacy of iodine nutrition was also confirmed by the high level of urinary iodine determined. Hence the author opined that the goiter might be an outcome of either iodine excess (iodine goiter) or iodine-deficient goiter arising from unavailability to the thyroid tissues, of dietary iodine. Excess iodine intake has symptoms similar to those of iodine deficiency and has been found to include abnormal growth of the thyroid gland, growth dysfunction, among others.

The present work investigates the cause of these goiters within the limits of our laboratory, focusing however on thyroid hormones - triiodothyronine, tetraiodothyronine and thyroid stimulating hormone(TSH) measurements. Some serum enzymes - aspartate aminotransferase (AST) and alanine aminotransferase (ALT) activities were measured. Finally determined was the evidence of hydrogencyanide (a notorious goitrogen in common foodstuff), in the blood and urine samples of subjects.

\section{METHOD}

Instruments: Instruments used include UV visible spectrophotometer, model 6405, and flame photometer, all product of Jenway, England.

Chemicals/Reagents : Potassium permanganate and potassium thiocyanate were Analar grade $\mathrm{BDH}$ Chemical, England. Picric acid was a product of Lab. Tech. Chemicals, India. Commercial ELISA kits for aspartate aminotransferase (AST), alanine aminotrasferase (ALT), and thyroid hormones were from CLINOTECH Diagnostics and Pharmaceuticals, Inc. Canada.

Sample Collection: Blood and urine samples were obtained from fifty (50) volunteer persons, (some of whom were university students), who formed the control group; while the test group was constituted by those with visible thyroid enlargement who willingly volunteered to join the study. Informed consent of all subjects was obtained in accordance with the ethnical consideration in operation at the medical centre, Niger Delta University.

Five millimeters of blood was obtained by peripheral venopuncture, centrifuged and stored at $-20^{\circ} \mathrm{C}$ in a freezer until required for analysis within a week. Samples of twenty-four hours urine collection were obtained from subjects and kept at $2-8^{\circ} \mathrm{C}$ in the refrigerator until required for analysis within the week.

Determination of Thiocyanate in Serum and Urine: The determination of thiocyanate was carried out according to the modified method explained by Haque and Bradbury, (1999). Into $1.0 \mathrm{ml}$ sample was added $0.1 \mathrm{ml}$, each of dilute $\mathrm{H}_{2} \mathrm{SO}_{4}(1 \mathrm{~mol} / \mathrm{L})$ and $\mathrm{KMnO}_{4}$ solution $(1 \mathrm{~mol} / \mathrm{L})$. The resultant solution was incubated at $30^{\circ} \mathrm{C}$ for 16 hours after addition of $4 \mathrm{ml}$ picrate solution. Absorbance was read at $510 \mathrm{~nm}$ against a reagent blank.

Determination of Thyroid Hormones $-T_{3}, T_{4}$ and TSH: Automated test kit method of ELISA was employed according to the instructions provided by the manufactures, (CLINOTEC Diagnostics). In this method the sample, assay buffer and enzyme conjugate were added to the wells coated with antihormone monoclonal antibody, and incubate for 60 minutes at room temperature, $18-26^{\circ} \mathrm{C}$. The hormone (the analyte) in the patient's serum competes with a hormone - enzyme (HHRP) conjugate for binding 
sites. Unbound hormone (analyte) and that of enzyme conjugate were washed off using working wash buffer. This was followed by the addition of $100 \mu \mathrm{l}$ TMB substrate and incubated for 13 minutes, after which "stop solution" was added, mixed and absorbance read on ELISA Reader at 450nm within 15 minutes. The unknown concentration was determined by extrapolating from the standard curve prepared using the values on each vial and their measured optical density.

Determination of iodine in Urine and Serum Samples: Into $5 \mathrm{ml}$ aliquots of centrifuged urine samples $(0.2 \mathrm{ml}$ in case of serum), was added $1 \mathrm{ml}$ citrate buffer, mixed properly and left to stand for one minute. This was followed by the addition of $1 \mathrm{ml}$ Leuco-crystal violet reagent and $8 \mathrm{ml}$ of distilled water. After 10minutes of color development, the absorbance was read in a spectrophotometer at $592 \mathrm{~nm}$.

Determination of Sodium and Potassium in Serum Samples: The elements in serum were determined using Flame Photometer-Spectrum Lab 7525, B-Bran Scientific and Instrument Company, England. The unknown sample concentration was determined from the standard curve prepared using known concentrations of the working standards of the elements sodium and potassium with wavelengths 589.0 and $766.5(\mathrm{~nm})$ respectively.

\section{RESULTS}

Fifty-seven volunteer subjects (both sexes) participated in the present study. Subjects were divided into 2 main groups - the control groups comprising of male and female control groups having about 25 subjects each; and the test group having only 7 female volunteer subjects. Parameters investigated include serum and urinary thiocyanate, and thyroid hormones. Others are the activities of serum enzymes - alanine aminotransferase (ALT) and aspartate aminotransferase (AST); and the levels of the elements_sodium, potassium and iodine.

The mean $( \pm S D)$ serum and urinary thiocyanate levels determined from the male control group were significantly higher than their female counterparts $(p<0.05)$. The level determined from the test group, $154 \pm 17.32 \mu \mathrm{g} / \mathrm{L}$, was significantly higher than those of male and female control groups $(p<0.05)$, (Table 1$)$.
Table 1: $\quad$ Mean $( \pm$ SD) Levels of Thiocyanate $(\mu \mathrm{g} / \mathrm{L})$ in Urine and Serum of Control and Test Groups

\begin{tabular}{|l|lll|}
\hline Subjects & \multicolumn{2}{|l|}{$\begin{array}{l}\text { Urine } \\
\text { Thiocyanate }\end{array}$} & $\begin{array}{l}\text { Serum } \\
\text { Thiocyanate }\end{array}$ \\
\hline $\begin{array}{l}\text { Control group } \\
\text { (females) }\end{array}$ & $\begin{array}{l}84.67 \pm 30.80 \\
(\mathrm{n}=25)\end{array}$ & $\begin{array}{l}78.35 \quad \pm 31.30 \\
(\mathrm{n}=20)\end{array}$ \\
\hline $\begin{array}{l}\text { Control group } \\
\text { (males) }\end{array}$ & $\begin{array}{l}104.70 \quad \pm 1.93 \\
(\mathrm{n}=25\end{array}$ & $\begin{array}{l}100.40 \quad \pm 11.09 \\
(\mathrm{n}=20)\end{array}$ \\
\hline $\begin{array}{l}\text { Test group } \\
\text { (females) }\end{array}$ & $\begin{array}{l}154.00 \quad \pm 17.32 \\
(\mathrm{n}=3)\end{array}$ & - \\
\hline
\end{tabular}

The serum levels of thyroid hormones, $T_{3}$, and $T_{4}$ were $0.9 \pm 0.36 \mathrm{ng} / \mathrm{mL}$ and $2.13 \pm 0.50 \mu \mathrm{g} / \mathrm{dL}$ respectively for the test group, and were lower than the control levels, $1.83 \pm 0.80 \mathrm{ng} / \mathrm{mL}$ and $5.40 \pm 0.27 \mu \mathrm{g} / \mathrm{dL}$, in that order. Contrarily, TSH level was $1.80 \pm 1.14 \mu \mathrm{lU} / \mathrm{mL}$ in the test group and higher than the level $1.20 \pm 0.44 \mu \mathrm{IU} / \mathrm{mL}$ determined in the control group (table 2). Also the levels of urinary $T_{3}$, $1.27 \pm 0.12 \mathrm{ng} / \mathrm{mL}$ and TSH $0.97 \pm 0.15 \mu \mathrm{lU} / \mathrm{mL}$ in the test subjects, were found to be lower than those in the control group, $5.95 \pm 0.92 \mathrm{ng} / \mathrm{mL}$ and 1.15 $\pm 0.2 \mu \mathrm{lU} / \mathrm{mL}$ in that order (Table 3).

Table 2: Serum Cconcentration of Biochemical Parameters in Control and Test Groups

\begin{tabular}{|c|c|c|}
\hline $\begin{array}{l}\text { Parameter } \\
\text { in Serum }\end{array}$ & $\begin{array}{l}\text { Mean } \quad( \pm S D) \\
\text { conc. } \\
\text { in Test group } \\
(F)\end{array}$ & $\begin{array}{lr}\text { Mean } & ( \pm \mathrm{SD}) \\
\text { concentration in } \\
\text { control } & \text { group } \\
\text { (males } & \& \\
\text { females) } & \end{array}$ \\
\hline $\mathrm{T}_{3}(\mathrm{ng} / \mathrm{mL})$ & $0.9 \pm 0.360$ & $1.833 \pm 0.81$ \\
\hline $\left.\mathrm{T}_{4} \mu \mathrm{g} / \mathrm{dL}\right)$ & $2.133 \pm 0.50$ & $5.40 \pm 0.27$ \\
\hline $\mathrm{TSH}(\mu \mathrm{IU} / \mathrm{mL})$ & $1.8 \pm 1.14$ & $1.20 \pm 0.44$ \\
\hline AST(IU/L) & $11.667 \pm 3.51$ & $8.67 \pm 0.58$ \\
\hline $\mathrm{ALT}(\mathrm{IU} / \mathrm{L})$ & $8.00 \pm 3.00$ & $4.67 \pm 0.58$ \\
\hline $\mathrm{Na}(\mathrm{mM} / \mathrm{L}$ & $136.333 \pm 3.51$ & $137.67 \pm 1.53$ \\
\hline $\mathrm{K}(\mathrm{mM} / \mathrm{L})$ & $3.767 \pm 0.25$ & $3.67 \pm 0.21$ \\
\hline
\end{tabular}


Table 3:

\section{Urine levels of Biochemical Parameters in Test and Control groups}

\begin{tabular}{|l|l|l|}
\hline $\begin{array}{l}\text { Analytes } \\
\text { in Urine }\end{array}$ & $\begin{array}{l}\text { Mean( } \pm \text { SD) } \\
\text { Concentration } \\
\text { in Test group } \\
\text { (females) }\end{array}$ & $\begin{array}{l}\text { Mean( } \pm \text { SD) } \\
\text { Concentration } \\
\text { in Control } \\
\text { Group (both } \\
\text { sexes) }\end{array}$ \\
\hline $\mathrm{T} 3(\mathrm{ng} / \mathrm{mL})$ & $1.27 \pm 0.115$ & $5.95 \pm 0.92$ \\
\hline $\mathrm{T} 4(\mu \mathrm{g} / \mathrm{dL})$ & $1.83 \pm 0.252$ & $1.80 \pm 0.28$ \\
\hline $\mathrm{TSH}(\mu \mathrm{lU} / \mathrm{mL})$ & $0.97 \pm 0.153$ & $1.15 \pm 0.21$ \\
\hline
\end{tabular}

Other parameters such as serum enzymes, AST and ALT had values $11.67 \pm 3.51$ and $8.00 \pm 3.00 \mathrm{IU} / \mathrm{L}$ (respectively) determined from the test group, which were higher than those of their controls (Table 2). On the other hand there was no significant difference between the serum levels of $\mathrm{Na}^{+}$and $\mathrm{K}^{+}$in the test group and that of the control subjects $(p>0.05)$.

The levels of urinary iodine determined showed that a large number of control subjects, (both sexes), had urinary iodine values between $140-269 \mu \mathrm{g} / \mathrm{L}$, while about 7 persons had values between $70-129 \mu \mathrm{g} / \mathrm{L}$ (Table 4). Contrarily serum iodide concentration was between $40-99 \mu \mathrm{g} / \mathrm{L}$ (Table 5). Comparison between serum iodide concentration obtained from smokers/ alcohol users on one hand, and on the other, nonsmokers/non alcohol users, showed a near similar spread (Tables 6 \& 7).

Table 4: Urinary lodine Concentration ( $\mu \mathrm{g} / \mathrm{L}$ ) in University Students

\begin{tabular}{|l|c|c|c|}
\hline Class & Class interval & Frequency & Cumulative frequency \\
\hline 1. & $70-79$ & 2 & 2 \\
\hline 2. & $80-89$ & 2 & 4 \\
\hline 3. & $90-99$ & 1 & 5 \\
\hline 4. & $100-109$ & - & 6 \\
\hline 5. & $110-119$ & 1 & 7 \\
\hline 6. & $120-129$ & 1 & - \\
\hline 7. & $130-139$ & - & 8 \\
\hline 8. & $140-149$ & 1 & 11 \\
\hline 9. & $150-159$ & 3 & 13 \\
\hline 1.0 & $160-169$ & 2 & 15 \\
\hline 11. & $170-179$ & 2 & 20 \\
\hline 12. & $180-189$ & 5 & 25 \\
\hline 13. & $190-199$ & 5 & 28 \\
\hline 14. & $200-209$ & 3 & 33 \\
\hline 15. & $210-219$ & 5 & 37 \\
\hline 16. & $220-229$ & 4 & 40 \\
\hline 17. & $230-239$ & 3 & 45 \\
\hline 18. & $240-249$ & 5 & 47 \\
\hline 19. & $250-259$ & 2 & 49 \\
\hline 20. & $260-269$ & 2 & - \\
\hline 21. & $270-279$ & - & 50 \\
\hline 22. & $280-289$ & 1 & \\
\hline & & & \\
\hline
\end{tabular}


Am. J. Food. Nutr, 2011, 1(4): 193-200

Table 5: Serum lodine Concentration ( $\mu \mathrm{g} / \mathrm{L})$ of University Students in Bayelsa.

\begin{tabular}{|c|c|c|c|}
\hline Class & Class interval & Frequency & Cumulative frequency \\
\hline 1. & $40-49$ & 3 & 3 \\
\hline 2. & $50-59$ & 7 & 10 \\
\hline 3. & $60-69$ & 7 & 17 \\
\hline 4. & $70-79$ & 11 & 28 \\
\hline 5. & $80-89$ & 12 & 40 \\
\hline 6. & $90-99$ & 9 & 49 \\
\hline 7. & $100-109$ & 1 & 50 \\
\hline
\end{tabular}

Table 6: Serum lodine Concentration $(\mu \mathrm{g} / \mathrm{L})$ in Male Smokers and Alcohol users

\begin{tabular}{|c|c|c|c|}
\hline Class & Class interval & Frequency & Cumulative frequency \\
\hline 1. & $40-49$ & 1 & 1 \\
\hline 2. & $50-59$ & 3 & 4 \\
\hline 3. & $60-69$ & 3 & 7 \\
\hline 4. & $70-79$ & 5 & 12 \\
\hline 5. & $80-89$ & 5 & 17 \\
\hline 6. & $90-99$ & 4 & 21 \\
\hline 7. & $100-109$ & 1 & 22 \\
\hline
\end{tabular}

Table7: Serum lodine Concentration $(\mu \mathrm{g} / \mathrm{L})$ in Non-Smokers and Non-Alcohol users

\begin{tabular}{|c|c|c|c|}
\hline Class & Class interval & Frequency & Cumulative frequency \\
\hline 1. & $40-49$ & 2 & 2 \\
\hline 2. & $50-59$ & 5 & 7 \\
\hline 3. & $60-69$ & 5 & 12 \\
\hline 4. & $70-79$ & 7 & 19 \\
\hline 5. & $80-89$ & 4 & 23 \\
\hline 6. & $90-99$ & 5 & 28 \\
\hline
\end{tabular}

\section{DISCUSSION}

The present work is carried out as a part of the investigative studies designed to determine the aetiology of goiter or thyroid enlargement observed among some persons in Bayelsa state. Because earlier work determined high levels of iodine in foods and urine samples of subjects, the observed goiter was thought to be unrelated to iodine-deficiency diseases (IDDs), (Madukosiri, 2011). In fact iodine excess was thought to be the root cause of the problem. The present pilot study has further examined other parameters in serum and urine so as to better determine the aetiology of those goiters; and they include, thyroid hormones - T3, T4, and TSH; enzymes - AST and ALT; electrolytes - $\mathrm{Na}^{+}$and $\mathrm{K}^{+}$; thiocyanate, and iodine measurements.

Serum and Urinary Levels of Thyroid Hormones: Thyroid hormone concentration in both serum and urine samples serve as useful indices of iodine deficiency disorders, such as hyperthyroidism, hypothyroidism and endemic goiter, among others. This study has determined lower levels of $T_{3}, T_{4}$ and higher level of TSH in the test group than in their control counterpart. The diminished levels of $\mathrm{T}_{3}$ and $\mathrm{T}_{4}$ and the correspondingly high level of $\mathrm{TSH}$ determined were suggestive of iodine-deficient goiter (Tulsawani et al., 2005). 
Low production of the thyroid hormones may occur due to a variety of reasons. One such factor is unavailability of iodine for the synthesis of thyroid hormones $T_{3}$ and $T_{4}$. This in turn could occur as a result of low dietary supply of the micronutrient, or the presence of goitrogens in food substances which inhibit the dietary or absorbed iodine utilization. Other dietary factors which could mediate negatively are protein/energy malnutrition and high calcium intake, (Knudson et al., 2002). Protein/energy malnutrition can undermine iodine, thyroid hormone transport and delivery to the tissues. Under such circumstances the affected transport and carrier proteins would include thyroid-binding globulin (TBG), albumen, and transthyretin (pre-albumin). Besides, known risk factors of low hormone production are micro-mineral deficiencies, particularly those of selenium, zinc and copper. These elements are components of some enzymes required for thyroid hormone synthesis. One such enzyme is deiodinase necessary for the conversion of $T_{4}$ to $T_{3}$ - the metabolically active form, (Tulsawani et al., 2005).

The effectiveness of TSH in iodine trapping is another side of the coin. Problems directly or indirectly affecting the pituitary gland or the hypothalamus would diminish the activity of iodide trapping or iodide pump in the thyroid cells leading to low production of hormones with consequent IDDs.

Serum and Urinary Thiocyanate: The adverse effect of thiocyanate in the body has continued to raise interest and observation (Oshintokun, 1998; Altamir et al., 2002; Tulsawani et al., 2005). Serum and urinary thiocyanate levels are indicative of hydrocyanate load of the body, and had been implicated in goiter development (Akindahunsi 1994; Kunudson et al., 2004). The present study has determined significantly higher levels of thiocyanate in the test group than in its counterpart controls $(p<0.05)$. Levels determined from the test subjects were all higher than the reference toxicity level given in the literature, (UTMB, 2010). According to this reference, potential toxicity level was given as $>100 \mathrm{mcg} / \mathrm{mL}$, while therapeutic range was 50 $100 \mathrm{mcg} / \mathrm{mL}$. The mean levels determine from the control subjects (males and females groups) were within the cited critical levels. These results support an implied role for thiocyanate in the incidence of goiter in Bayelsa State.

Apart from being implicated in goiter development, cyanide, on longtime exposure, has been associated with oxidative stress leading to other degenerative and neurological disorders (Oshintokun, 1981;
Tulsawani et al., 2005). This was attributed to the ability of the compound to deactivate certain enzymes which contain metal ions by forming a stable complex with them. The susceptible enzymes include deiodinase, brain cytochrome c oxidase and rhodanase, among others (Tulsawani et al., 2005). The development of oxidative stress was related to the propensity of cyanide to induce lipid peroxidation by inpairing the antioxidant defence enzymes such as catalase, superoxide dismutase and glutathione peroxidase.

Although food is the main source of cyanide ions in the body, inhalation through the lungs or absorption through the mucus membrane can also occur. Major food sources are the Cruciferae family of vegetables that contain cyanoglucosides, which when hydrolyzed liberate the goitrogen, hydrogen cyanide. These cruciferous vegetables include cassava, broccoli, cauliflower, lima beans, brussels, millet, bamboo shoots, and sweet potatoes (Fowke et al., 2001; Montgomery, 1980).

Cassava is a major staple food in Bayelsa as in some other regions in Africa, particularly in West Africa. The amount of hydrogen-cyanide consumption is in part, a function of the method of processing of cassava products and disposal of processing water. The number of uses to which cassava is put into is also an important determinant of intake levels. The fact that cassava appears in many of their diets (in different varieties and forms), is recognized as an important factor capable of raising the overall daily toxicant intake.

Serum AST and ALT Activities: The activities of the enzymes aspartate aminotransferase (AST) and alanine aminotransferase (ALT) were found to be enhanced in subjects with visible goiters. Contrarily those of the control group did not show such pattern of increase. These changes suggest a possible presence of hepatic lesion such as liver necrosis. Other workers had also reported a hydropic degeneration of the hepatocytes in cyanide exposure (Altamir et al., 2002).

Other serum analytes determined are the electrolytes- $\mathrm{Na}^{+}$and $\mathrm{K}^{+}$. The present work recorded $\mathrm{Na}^{+}$ranges of $132.82-139.84 \mathrm{Mm} / \mathrm{L}$ in the test group as against $136.13-139.2 \mathrm{Mm} / \mathrm{L}$ determined from the control $(p<0.05)$. This is in consonant with our previous work, (Madukosiri and Adoga, 2002). The normal levels of both elements determined in present work may be interpreted as normal activity of the 
Am. J. Food. Nutr, 2011, 1(4): 193-200

pump system and seems not to be affected by thiocyanate nor thyroid hormone levels.

Effect of Alcohol and Tobacco Usage: Alcohol and tobacco smoking have been shown to have a contradictory effect on the prevalence of iodinedeficient goiter (Knudsen et al., 2002). According to this reference, while tobacco smoking was considered as a risk factor, alcohol use had a lowering effect on development of disease. The present work seems to be in line with this reference in the sense that the observed frequency distributions in the two groups appear to have similar spread (tables 6 \& 7).

In summary we have determined lower mean values of $T_{3}$ and $T_{4}$ from subjects with visible goiters than in their control counterparts, despite high levels of serum and urinary iodine. The levels of the thyroid hormone, TSH, determined in the test group were expectedly higher than those in the control group and that of the literature recommendation. Although high levels of thiocyanate were determined from all groups, those from the test subjects were higher than the critical levels given in the literature. These results are pointers to iodine deficiency diseases (IDDs) possibly arising from the toxicity effect of high levels of the goitrogen - thiocyanate in the body. The mechanism by which thiocyanate inhibits iodine metabolism is beyond the scope of the present paper. Further investigation should attempt to demonstrate the possible mechanism of toxicity and the goitrogenic effect of thiocyanate.

\section{ACKNOWLEDGEMENT}

I am pleased to acknowledge the effort of those who contributed meaningfully towards the completion of the present work. My gratitude goes to Dr. E.T Omu, the Consultant Physician and Director of Medical Services, and Mr. Diete Spiff, the Chief Lab. Technologist, Niger Delta University, Bayelsa. Others worthy of mention who worked tirelessly both in sampling and laboratory work to bring this research work to present state include my project students, $\mathrm{Mr}$. N.C. Degi; Mrs P.R. Ukulor; M.E. Ola; D.J Benson and a beloved Nursing officer, Mrs. T.J. Jordan. Finally I thank Mr. O. Alali, Department of Chemical Pathology, University of Port Harcourt Teaching Hospital, for his assistance during the hormonal assay.

\section{REFERENCES}

Abuye C; U. Kelbessa, S. Wolde-Gabriel,(1998). Health effects of cassava consumption in south Ethiopia East Africa. Med. J. 75: 166-170.

Adewusi S.R.A; Akindahunsi A.A (1994). Cassava processing, consumption and cyanide toxicity. Journal Toxicol. Environ. Health. 43:13 - 23.

Akoroda M. O; Oyinlola A. E and Grebremeskel. T. (1987). Plantable stem supply system for IITA, Cassava varieties in Oyo State of Nigeria. Agricultural systems 24 (4):305 - 317.

Altamir B. Sousa; Benito Soto-Blanco, Jose L. Guerra, Edna T. K.Imura, Silvana L. G. (2002). Does prolonged exposure to thiocyanide toxicity promote hepatotoxicity and nephrotoxicity? Toxicology, 174:87-95

Baned - Medhin M, Rosling H, (1997). Geographical and seasonal association between linamarine and cyanide exposure from cassava and the upper motor neurone disease konzo in former Zoure. Trop Med. Int. Health 2:1143- 51 .

Felig, Philip; Frohman, Lawrence A. (2001). "Endemic goiter, Endocrinology and Metabolism. McGraw - Hill Professional. ISBN 9780070220010.http://books.google.com/?id=AzuuGrp byUgc7pg=RAI-PA351.

Fowke J.H; Fahey,J.W; Stephenson, K.K and Hebert J.R. (2001). Using Isothiocyanate excretion as a biological marker of Brassic vegetable consumption in epidemiological studies.: Evaluating the sources of variability. Public Health Nutriton, June; 4 (3): 837-46.

Ghawabi S.H; M.A. Gaafar, A.A. El-Saharti, H.M. Soheir, K. Kamelia, R. Fares (1975). Chonic cyanide : a clinical, radioisotope, and laboratory study. Br. J. Ind. Med. 32, 215-219.

Haque M.R. and J.H. Bradbury (1999). Simple Method for Determination of Thiocyanate in Urine. Clinical Chemistry, 45: 9, 1459 - 1464

Hetzel B.S (1983). lodine deficiency disorders (IDD) and their eradication, Lancet 2, $1126-1127$

Knudsen N, Laurberg P, Pwmild H; Rulow I; Ovesen L; Jorgensen T (2002). "Risk factors for goiter and thyroid nodules" thyroid: official journal of the American thyroid Association d12 (10):879-88

Madukosiri C.H. and Ikale E.(2011). lodine content in diet and urine of people in Imiringi and Otuasega communities in Ogbia LGA Bayelsa. Electronic Journal of Environment, Agriculture and Food Chemistry, 10(5), 2216-2221.

Madukosiri C. H and Adoga G. I. (2011). Elemental status of pregnant and lactating women in Bassa LGA of Plateau State, Nigeria. Pakistan Journal of Nutrition. 10(5) $401-404$. 
Montgomery RD. (1980). Cyanogens. In: Liener IE, (Ed). Toxic constituents of plant foodstuffs. , Academic Press, New York, $143-60$.

Osuntokun B. O. (1981) Cassava diet, Chronic cyanide intoxication and neuropathy in Nigerian Africans. World rev Nutr. Diet 36, 141 k- 173.

Smith P.P (2001). 'Role of iodine in antioxidant defence in thyroid and breast disease'. Biofactors (Oxford, England). 19 (3-4): 121-30.

Tulsawani, R.K; M. Debnath, S.C Pant, OM Kumar, A.O Prakash, R. Viyayaraghavan, R. (2005). Bhattacharya.
Effects of sub-acute oral cyanide administration in rats: Protective efficacy of alpha-ketoglutarate and sodium thiosulfate. Chemico-Biological Interactions. 156, 1:12.

University of Texas Medical Branch (UTMB) (2009). THIOCYANATE, serum. Laboratory Survival Guide. Pathology Clinical Services, Department of pathology, Texas, 087-0531.

WHO, UNICEF, ICCIDD (2001); Assessment of iodine deficiency disorders and monitoring their elimination. A guide for Programme Managers, $2^{\text {nd }}$ ed. World Health Organisation, Geneva . 7 - 40. 